\title{
イミン類への炭素ラジカル付加反応の開発
}

\author{
宮 部 豪人
}

\section{Development of Carbon Radical Addition to Imine Derivatives}

\author{
Hideto MiYABE \\ Graduate School of Pharmaceutical Sciences, Kyoto University, Yoshida 46-29, \\ Sakyo-ku, Kyoto 606-8501, Japan
}

(Received January 22, 2003)

\begin{abstract}
This review summarizes the new carbon-carbon bond construction methods based on the radical reaction of imine derivatives. The intermolecular carbon radical addition to oxime ethers proceeded smoothly in the presence of $\mathrm{BF}_{3}$. $\mathrm{OEt}_{2}$. A high degree of stereocontrol in the reaction of oxime ethers was achieved to give amino acid derivatives with excellent diastereoselectivities. The radical reaction of imine derivatives in water has also been investigated. The radical cyclization of oxime ethers proceeded effectively to provide the functionalized heterocycles via a carbon-carbon bondforming process. These reactions were extended to the solid-phase radical reactions using triethylborane or diethylzinc as a radical initiator.
\end{abstract}

Key words_ _ radical; imine; oxime ether; amino acid; solid-phase reaction; water

\section{1. はじめに}

イミン類への求核付加反応はアミン類を合成する 有用な方法であり，一般には有機金属試薬が用いら れる. ${ }^{1-3)}$ 有機金属試薬は大変有効であるが, その 強い塩基性のために進行する基質のエナミン化，あ るいは還元的カップリング反応による二量化, マイ ケル型付加反応による $N$-アルキル体の生成などの 問題が生じることがある. さらに，イミン類の反応 性が低いことなどから，アリル化反応やベンジル化 反応などの例を除き，比較的有効な反応が少ないの が現状である. 著者らは, それらの欠点を克服すべ くイミン類への炭素ラジカル付加反応を開発してき た.

近年, ラジカル反応は官能基の保護や厳密な無水 条件を必要とせず，穏和な条件下で進行することか ら, 次世代の合成反応として注目を集めている. 特 に, 炭素一炭素結合を形成するラジカル反応は合成 化学的見地から興味深<, 炭素一炭素不飽和結合や

京都大学大学院薬学研究科 (下606-8501 京都市左京区 吉田下阿達町 46-29)

e-mail: hmiyabe@pharm.kyoto-u.ac.jp

*本総説は, 平成 15 年度日本薬学会奨励賞の受賞を記 念して記述されたものである.
炭素一へテロ原子不飽和結合への炭素ラジカル付加 反応が活発に研究されている.

2. オキシムエーテル類への分子間ラジカル付加 反応

イミン類のなかでも，オキシムエーテルやヒドラ ゾン類は, 生成する中間体アミニルラジカルが隣接 するへテロ原子により安定化されるため, 優れたラ ジカル受容体となることが知られている. ${ }^{4,5)}$ また, 安定で取り扱い易く, 対応するアルデヒドから容易 に合成でき, さらにラジカル付加反応後に生成する アルコキシアミンやヒドラジンは還元的にアミンに 変換できる. しかし, オキシムエーテルやヒドラゾ ン類のラジカル反応は, 分子内反応を中心として発 展しており, ${ }^{6-12)}$ 分子間反応はほとんど研究されて いなかった. ${ }^{13-17)}$ 最近, 著者らは, オキシムエー テル類 1 への分子間ラジカル付加反応が, ルイス酸 として $\mathrm{BF}_{3} \cdot \mathrm{OEt}_{2}$ を添加した場合に効率よく進行

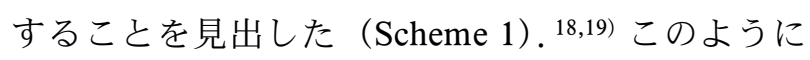
ルイス酸により反応が促進されたことから, アルド キシムエーテル類は求電子的なラジカル受容体とし て反応していることが判り, その LUMO と求核的 な炭素ラジカルの SOMO が反応したと考えられ る. 本反応は, 幅広いアルドキシムエーテル類に応 
用できることから有機金属試薬の求核付加反応に並 ぶ有用な方法になると期待している.

現在，ラジカル反応は重金属化合物やスズ化合物 に依存しており，それらを用いない安全な原子移動 反応や一電子移動反応の開発が不可欠である。そこ で, $\mathrm{Et}_{3} \mathrm{~B}$ と iso-PrI を用いたヨウ素原子移動機構に よるオキシムエーテル 3 へのラジカル付加反応を検 討した結果， $\mathrm{Bu}_{3} \mathrm{SnH}$ を用いなくても反応が進行す ることを見出した (Scheme 2). ${ }^{20,21)}$ さらに詳細に, 反応温度や溶媒などの影響を調べた（Fig. 1)。そ の結果, 目的の付加体 $\mathbf{4 a}$ とエチル体 $\mathbf{4 b}$ の生成比 は, 反応温度と溶媒に依存しており, トルエン中で 反応温度を上げることにより, $\mathrm{Et}_{3} \mathrm{~B}$ を用いた場合 の副反応であるエチルラジカル付加反応をほぼ完全

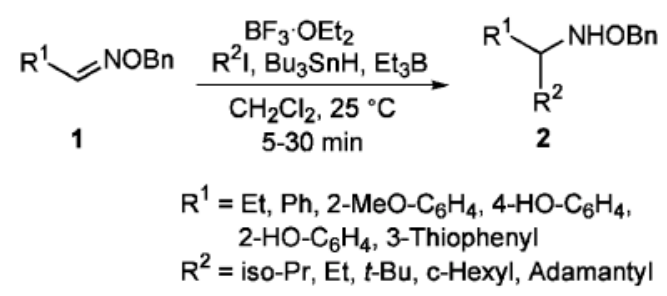

Scheme 1. Radical Addition to Oxime Ethers

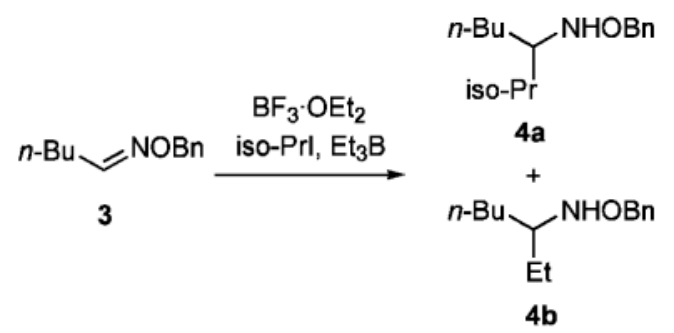

Scheme 2. Radical Addition via Iodine Atom-Transfer Process
に抑制できた。本反応では， $\mathrm{Et}_{3} \mathrm{~B}$ がラジカル開始 剂のみでなくラジカル停止剂としても働き，ラジカ ル連鎖反応が進行している（Scheme 3)。本ヨウ素 原子移動反応にはラジカル間に平衡が存在するため, $\mathrm{Et}_{3} \mathrm{~B}$ から発生したエチルラジカルよりも安定かつ 求核性が高い 2 級及び 3 級ラジカルが生成する場合 に有効な方法である，そのため，様々な 2 級及び 3 級ヨウ化アルキルが利用できるが， 1 級ヨウ化アル キルを用いた場合には $\mathrm{Et}_{3} \mathrm{~B}$ 由来のエチルラジカル 付加反応が優先する.

一般にラジカル反応の立体制御は難しく, 立体選 択的な反応の開発とその理論的な考察はラジカル反 応に残された最も重要な研究課題である. ${ }^{22}$ 著者ら は， $\alpha$-アミノ酸の不斉合成をモデル系に選び， ジ アステレオ選択的なラジカル付加反応を検討した (Scheme 4). ${ }^{23,24)}$ 特に, グリオキシル酸誘導体 5 は 隣接する電子吸引基により活性化されているため, オキシムエーテル 1 とは対照的に $\mathrm{BF}_{3} \cdot \mathrm{OEt}_{2}$ によ る活性化を必要とせず， $-78^{\circ} \mathrm{C}$ でも高い反応性を 示した。特に, $\mathrm{Bu}_{3} \mathrm{SnH}$ を用いた場合 (Method 1),

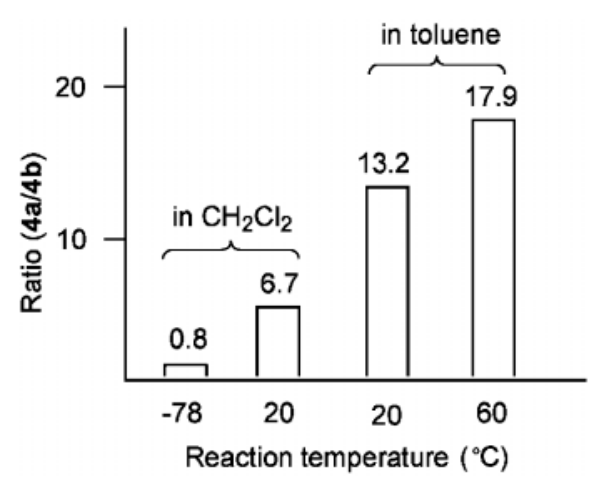

Fig. 1. Ratio of $\mathbf{4 a}$ to $\mathbf{4 b}$ in Radical Addition to $\mathbf{3}$

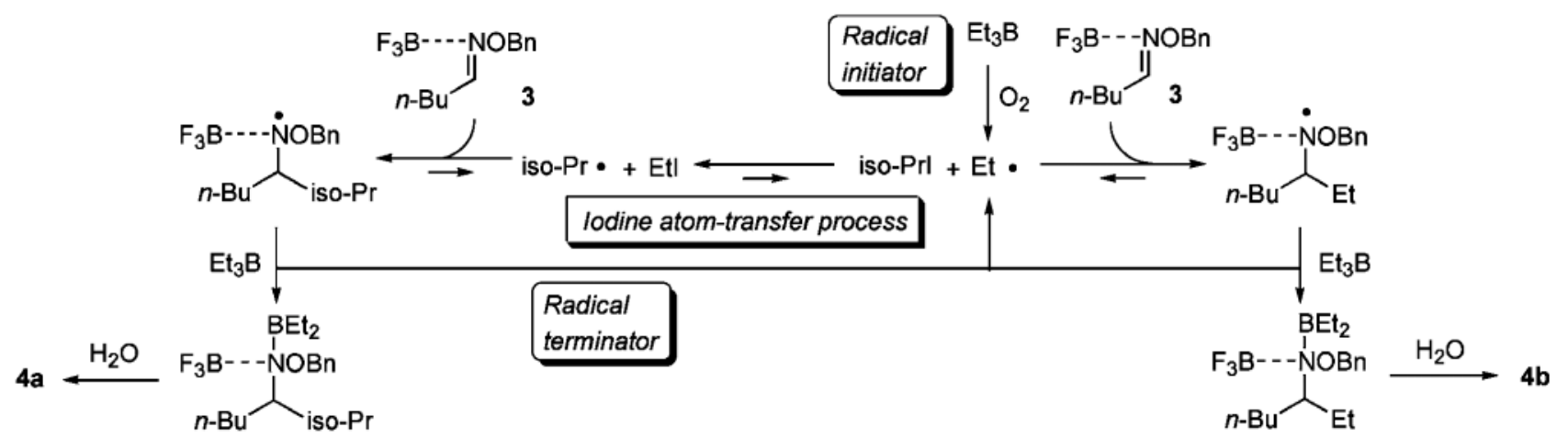

Scheme 3. Possible Reaction Pathway 
高収率かつ高ジアステレオ選択的に付加体 $\mathbf{6}$ を与え た。さらに，有機金属試薬を用いた場合に問題とな る $N$-アルキル化反応は全く起こらず，炭素ラジカ ルはオキシムエーテル基のイミノ炭素上に選択的に 付加したことから，本反応は $\alpha-ア ミ ノ$ 酸類の優れ た合成法である，アミノ酸への誘導に関しては，接 触還元あるいは $\mathrm{Mo}(\mathrm{CO})_{6}$ による脱ベンジルオキシ 化とカンファースルタムの除去を経て， $\mathrm{D}$-バリン 等 7 に導くと同時に絶対配置を決定した。グリオキ シル酸誘導体 $\mathbf{5}$ は，カルボニル基とスルホニル基の 双極子反発及びオキシムエーテル基とスルホニル基 の反発により, anti, s-cis 型を有利にとることが推 測される。そのため，アルキルラジカルはスルホニ
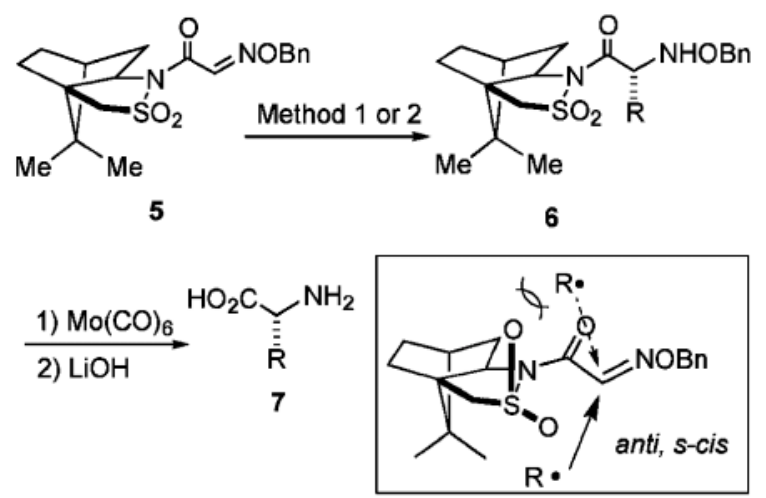

Method 1: $\mathrm{RI}, \mathrm{Bu}_{3} \mathrm{SnH}, \mathrm{Et}_{3} \mathrm{~B},-78^{\circ} \mathrm{C}$ (>98:2 - $95: 5 \mathrm{ds}$ ) Method 2: RI, $\mathrm{Et}_{3} \mathrm{~B}$ or $\mathrm{RI}, \mathrm{Et}_{2} \mathrm{Zn}, 25^{\circ} \mathrm{C}$ (ca. 90:10 ds)

Scheme 4. Asymmetric Synthesis of $\alpha$-Amino Acids
ル基の酸素原子との反発を避けるように反応して, $R$-アミノ酸が得られたと考えられる。次に, $\mathrm{Bu}_{3}$ $\mathrm{SnH}$ を用いないヨウ素原子移動ラジカル付加反応 (Method 2) を検討したところ，室温でラジカル間 のヨウ素原子移動反応が効率的に起こり, 目的のア ミノ酸誘導体 6 が得られた。 ジアステレオ選択性は, $\mathrm{Bu}_{3} \mathrm{SnH}$ を用いて $-78^{\circ} \mathrm{C}$ で行った反応より低下する ものの, 生成物のジアステレオマーがシリカゲルカ ラムクロマトグラフィーにより容易に分離できるこ とから， $\mathrm{Bu}_{3} \mathrm{SnH}$ を用いない本方法は現実的な方法 と言える。ささに， $\mathrm{Et}_{2} \mathrm{Zn}$ がラジカル開始剤として 働くという $\mathrm{Ryu}$ ら $^{25)}$ の報告を参考にして, $\mathrm{Et}_{2} \mathrm{Zn}$ を用いたヨウ素原子移動反応を検討した結果, $\mathrm{Et}_{2}$ $\mathrm{Zn}$ も $\mathrm{Et}_{3} \mathrm{~B}$ と類似の反応性を示すことが判明した。 本反応において, $\mathrm{Et}_{3} \mathrm{~B} や \mathrm{Et}_{2} \mathrm{Zn}$ はラジカル開始剤 のみでなく, ルイス酸やラジカル停止剤としても働 き，オキシムエーテル基の活性化とラジカル連鎖反 応の進行を促進していると考えられる.

次に，オキシムエーテルへのラジカル付加反応を 鍵段階とした $\beta$-アミノ酸類の合成を検討した (Scheme 5). 26,27) 基質としてオキシムエーテル 8 を 選び，連続する 2 回の立体選択的なアルキル化反応 を行った．オキシムエーテル 8 からアルキル体 9 ヘ のモノアルキル化反応には相間移動触媒を用いる反 応が有効であり，収率よくアルキル基を導入でき た。本反応で得られたアルキル体 9 は立体異性体の 混合物であり，例えば置換基 $\mathrm{R}^{1}$ がベンジル基の場 合には，異性体の比率が $(R, Z):(R, E):(S, Z)$

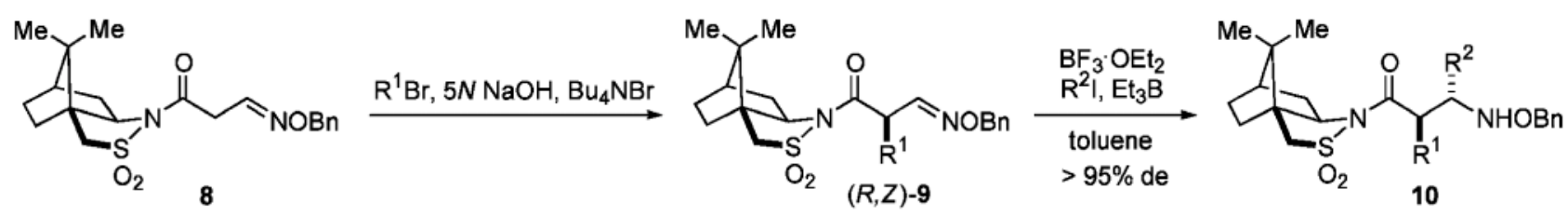

$R$ : Absolute configuration of newly-formed chiral center in $9 \quad R^{1}=\mathrm{Bn}, 4-\mathrm{NO}_{2}$-benzyl, Propargyl $Z$ : Geometry of oxime ether $\mathrm{R}^{2}=\mathrm{Et}$, iso-Pr, c-Hexyl, c-Pentyl, s-Bu, iso-Bu

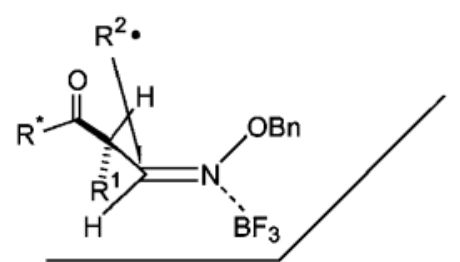

$\mathrm{R}^{*}=$ Camphorsultam

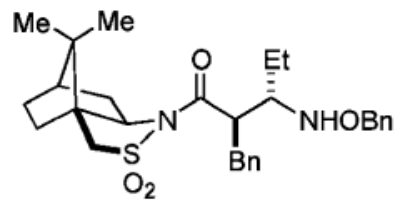

10a

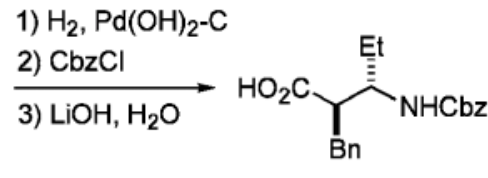

11

Scheme 5. Asymmetric Synthesis of $\beta$-Amino Acids 


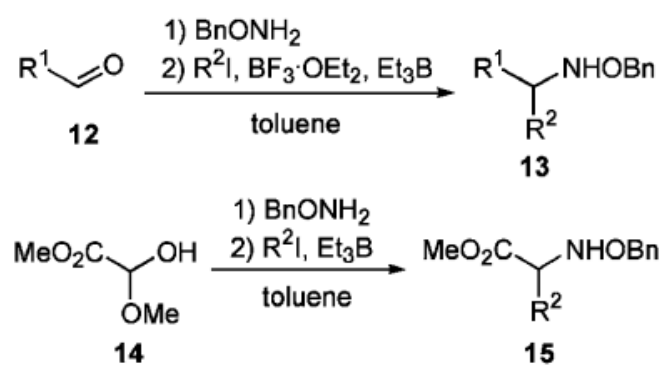

Scheme 6. One-Pot Reaction
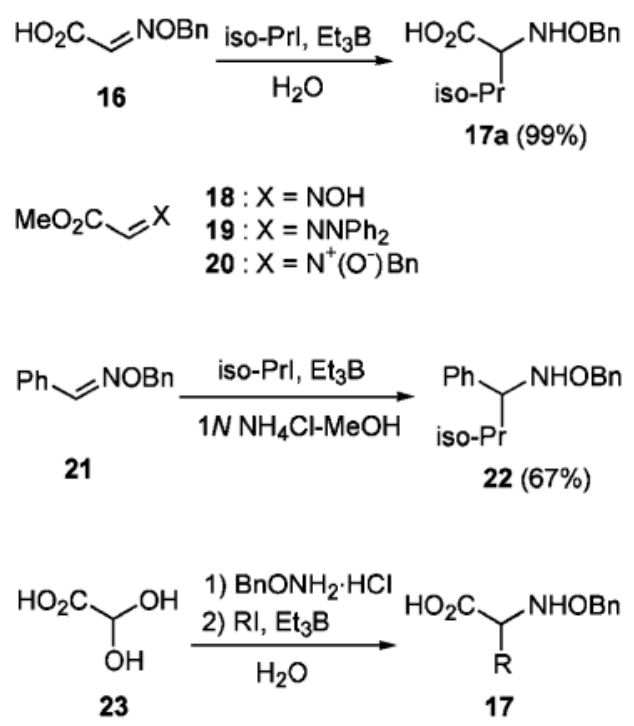

Scheme 7. Radical Reaction in Water

エーテル形成段階で生成する水によりラジカル反応 が阻害されないことを示している.

一般に, 中性炭素ラジカルは水に対して安定であ るため, 水溶媒中でのラジカル反応の開発が期待さ

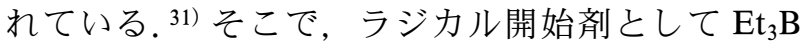
を用いて, 種々のイミン類への水中炭素ラジカル付 加反応を検討した（Scheme 7). ${ }^{32,33)}$ まず，水溶性 のグリオキシル酸オキシムエーテル 16 を用いて水 中でイソプロピルラジカル付加反応を行ったとこ ろ, 反応は 10 分で終了し, 目的のイソプロピル体 17a が定量的に得られた。 さらに，オキシム 18 , ヒ ドラゾン 19, ニトロン 20 の水中炭素ラジカル付加 反応を検討したところ，基質により反応性が大きく 異なるものの，いずれの場合も目的の付加体が得ら れた. 次に, アルドキシムエーテル $21 へ の$ 水中ラ ジカル付加反応を検討した. 活性化剂として $1 N$ $\mathrm{NH}_{4} \mathrm{Cl}$ を用いてラジカル反応を行ったところ, 目 的の付加体 22 が得られた。 さらに, 塩酸水溶液 中, 含窒素芳香環化合物 lepidineへのエチルラジカ ル付加反応も進行した. 次に, 本反応をアミノ酸類 の水中ワンポット合成に応用した. 水中で, グリオ キシル酸水和物 23 とベンジルオキシアミン塩酸塩 からオキシムエーテルを形成させた後, 続いてラジ カル反応を行い, アミノ酸 $\mathbf{1 7}$ を得た.

さらに, 一電子移動型ラジカル開始剤として, 種 々の金属を用いて水中ラジカル反応を検討した結 果，金属インジウムがラジカル開始剤として有用で 


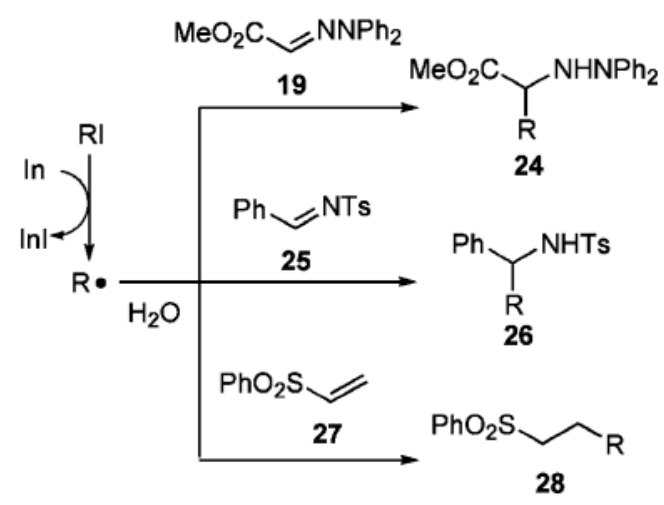

Scheme 8. Indium-Mediated Radical Reaction in Water

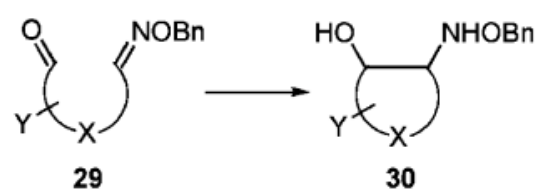

Method $1: \mathrm{Bu}_{3} \mathrm{SnH}, \mathrm{AlBN}$

Method 2 : $\mathrm{Sml}_{2}$, HMPA, $t$-BuOH

Scheme 9. Radical Cyclization of Oxime Ethers

あることを見い出した (Scheme 8). ${ }^{34,35)}$ インジウ ムは, ヒドラゾン 19への水中ラジカル付加反応に 有用であるのみでなく, $N$-スルホニルイミン 25 や 電子吸引基により活性化されたオレフィン類 $\mathbf{2 7}$ へ の水中ラジカル付加反応にも利用できた.

\section{4. ラジカル閉環反応の開発と応用}

著者らの研究室では, オキシムエーテル基をラジ カル受容体として用いたラジカル閉環反応の研究を 展開している. ${ }^{36)}$ 特に, 複数の官能基を有する環状 化合物の合成を目指して, カルボニル基とオキシム エーテル基を同一分子内に持つ基質 29 のラジカル 閉環反応を検討し, 環状アミノアルコール類 $\mathbf{3 0}$ の 合成を行ってきた (Scheme 9). その結果, 反応条 件としては， $\mathrm{Bu}_{3} \mathrm{SnH}$ と $\mathrm{AIBN}$ を用いる条件 (Method 1) と $\mathrm{SmI}_{2}$ を用いる一電子移動反応条件 (Method 2) が有効であることを見い出した。 ま た, 本反応の適応性は広く, カルボニル基としては アルデヒドやケトン, オキシムエーテル基としては アルドキシムエーテルやケトキシムエーテルに利用 できた.

著者らは, オキシムエーテル 31 のラジカル閉環 反応を $\mathrm{SmI}_{2}$ を用いて行った (Table 1). 37-40) オキ シムエーテル 31a の場合, tert-BuOH 存在下で反応
Table 1. $\mathrm{SmI}_{2}$-Induced Cyclization of Oxime Ethers
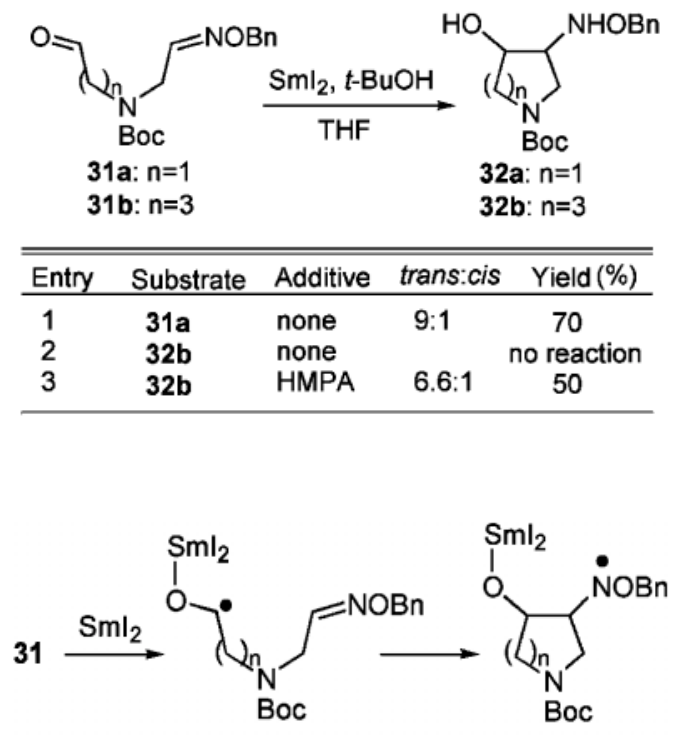

A B

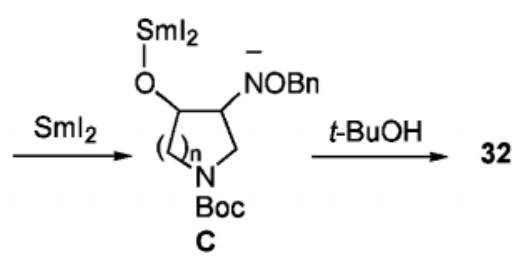

Scheme 10. Possible Reaction Pathway

は速やかに進行し， 5 員環生成物 32a が 70\% の収 率で得られた。一方, 7 員環生成物 32b の合成にお いては, $\mathrm{SmI}_{2}$ を活性化する HMPA の添加が不可 欠であった，本反応条件では， $\mathrm{SmI}_{2}$ のキレート効 果により, $\mathrm{Bu}_{3} \mathrm{SnH}$ を用いる方法 (Method 1) より も高いトランス/シス選択性が得られた．本反応は, $\mathrm{SmI}_{2}$ からの一電子移動によるケチルラジカル $\mathbf{A} の$ 生成によりはじまり, 続いてオキシムエーテル基と のラジカル閉環反応が起こり, アミニルラジカル $\mathbf{B}$ が生成する (Scheme 10)。さらに，このアミニル ラジカルが, $\mathrm{SmI}_{2}$ からの一電子移動によりアニオ ン C となり, 最後に tert-BuOH によるプロトン化 を経て, 生成物 $\mathbf{3 2}$ が得られたと考えられる.さら に, 本ラジカル反応を鍵反応として, プロテインキ ナーゼ C の強力な阻害活性を示す (-)-balanol 33 の全合成に成功した（Fig. 2).

次に, 2 つ炭素一炭素結合を一段階で形成する タンデム型炭素ラジカル付加一閉環反応を検討した (Scheme 11). ${ }^{41)}$ 反応基質となるオキシムエーテル 34 はマンニトールより調製した。オキシムエーテ 


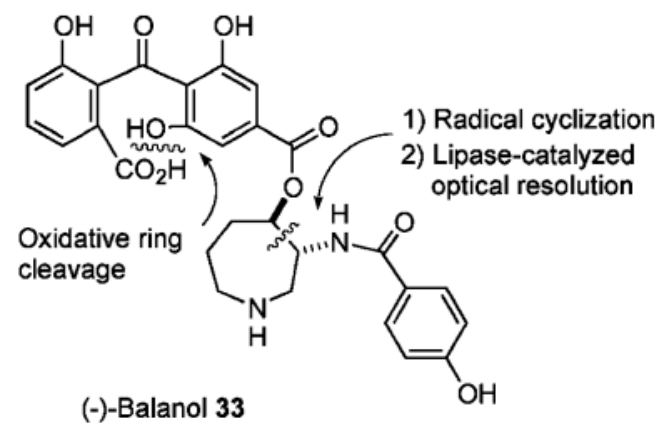

Fig. 2. Total Synthesis of (-)-Balanol

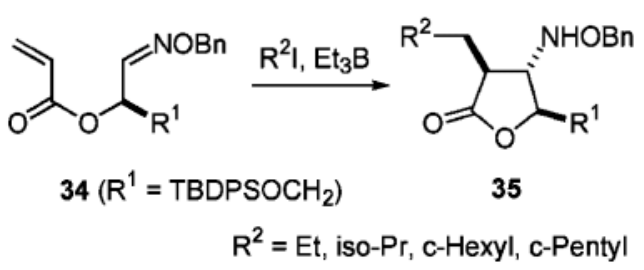

in bnezene (trans: cis $=12: 1$ )

in $\mathrm{H}_{2} \mathrm{O}-\mathrm{MeOH}$ (trans:cis = 7:1-9:1)

Scheme 11. Tandem Radical Reaction of Oxime Ether

ル 34 のタンデム型ラジカル反応を検討したとこ ろ, 目的の $\gamma$-ブチロラクトン $\mathbf{3 5}$ がジアステレオ選 択的に得られた。本反応は, Mannich 反応をラジ カル的に行った初めての例であり, ラジカル種とラ ジカル受容体の電子的性質を効果的に組み合わせた 反応である. すなわち, 第 1 ステップとして, 求核 的な炭素ラジカルが強い求電子的性質を有するラジ カル受容体 $\alpha, \beta$-不飽和カルボニル基側に選択的に 1,4-付加する (Scheme 12). 続いて, 第 2 ステップ として, 生成した炭素ラジカルはカルボニル基によ り求電子的となり, 酸素原子により電子密度の高ま つたオキシムエーテル基炭素に選択的に付加して閉 環反応が進行したものと考えられる。 また, 本反応 は水中においても進行している点で興味深く, タン デム反応がラジカル的に進行していることを示唆し ている，立体化学に関しては， $\mathrm{A}^{1,3}$ ストレインが最 も小さくなるようなコンフォメーションを有利にと つて反応が進行したものと考えられる.

\section{5. 固相ラジカル反応の開発}

近年のコンビナトリアルケミストリーの発展はめ ざましく，医薬や農薬の開発にとどまらず，機能性 物質や触媒開発のための重要な手法となりつつあ る. ${ }^{42-44)}$ しかし, コンビナトリアルケミストリー

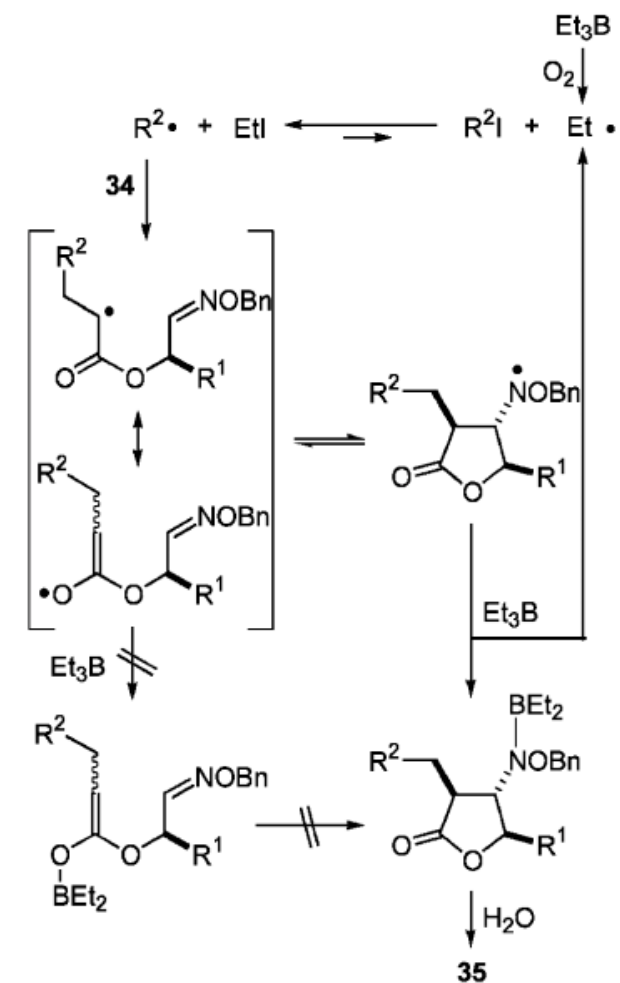

Scheme 12. Possible Reaction Pathway

の発展のためには, 固相上で高収率かつ高選択的に 炭素一炭素結合を形成する反応の開発が不可欠であ る，そこで，著者らは固相上で炭素一炭素結合を形 成するラジカル反応の開発に着手した. ${ }^{45,46)}$ これま で報告されてきた固相ラジカル反応としては, ラジ カル開始剤として $\mathrm{AIBN}, \mathrm{SmI}_{2}$ を用いた反応が数例 知られていた. ${ }^{47-52)}$ そのため, ラジカル開始剤 $\mathrm{Et}_{3}$ B を用いた固相反応が液相反応と同様に進行するか 否か興味が持たれる.

はじめに，ラジカル開始剤として $\mathrm{Et}_{3} \mathrm{~B}$ を用い て, オキシムエーテル 36 への固相ラジカル付加反 応を検討した (Scheme 13). 53) 反応操作としては, レジン体 36 のジクロロメタン懸濁溶液に試薬類を 滴下し, 室温で穏やかに一時間擋挥した後, レジン を溶媒で洗浄し，付加体 37a-g を得た。続いて， TFA を用いてレジンからの切り離した後, 精製を 行い, アミノ酸誘導 38a-g を得た. その結果, 2 級 ラジカルや 3 級ラジカルの tert-ブチルラジカルと の反応では収率良くアルキル体が得られたのに対し, 1 級ラジカルとの反応や非常に嵩高いアダマンチル ラジカルとの反応では, 収率が低下した。 特に, 固 相反応においては, 液相反応においてしばしば問題 

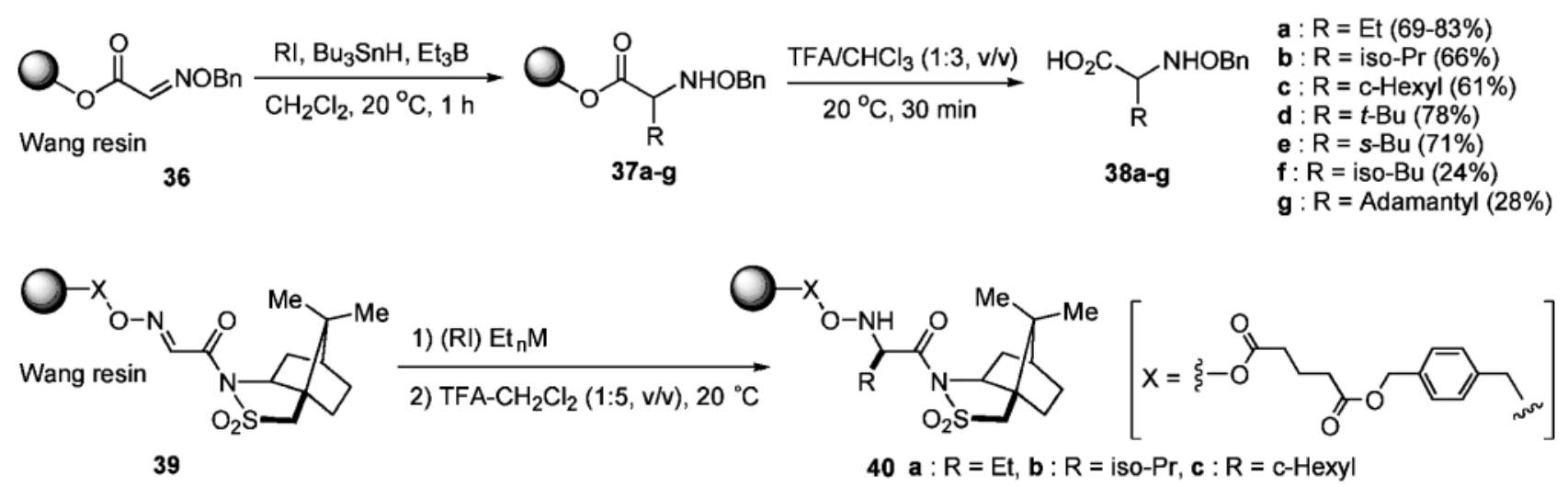

Scheme 13. Solid-Phase Radical Addition to Oxime Ethers

Table 2. Solid-Phase Radical Addition to Oxime Ether 39

\begin{tabular}{cllccc}
\hline \hline Entry & Initiator & \multicolumn{1}{c}{$\mathrm{R}$} & Product & Yield $(\%)^{a)}$ & Selectivity \\
\hline $1^{\mathbf{b})}$ & $\mathrm{Et}_{3} \mathrm{~B}$ & $\mathrm{Et}$ & $\mathbf{4 0 a}$ & 74 & $>95 \% \mathrm{de}$ \\
$2^{\mathbf{b})}$ & $\mathrm{Et}_{2} \mathrm{Zn}$ & $\mathrm{Et}$ & $\mathbf{4 0 a}$ & 67 & $>95 \% \mathrm{de}$ \\
$3^{\mathbf{c})}$ & $\mathrm{Et}_{3} \mathrm{~B}$ & $i s o-\mathrm{Pr}$ & $\mathbf{4 0 b}$ & 69 & $92 \% \mathrm{de}$ \\
$4^{\mathbf{c})}$ & $\mathrm{Et}_{3} \mathrm{~B}$ & $c$-Hexyl & $\mathbf{4 0 c}$ & 58 & $92 \% \mathrm{de}$ \\
$5^{\mathbf{c})}$ & $\mathrm{Et}_{2} \mathrm{Zn}$ & $i s o-\mathrm{Pr}$ & $\mathbf{4 0 b}$ & 53 & $90 \% \mathrm{de}$ \\
$6^{\mathbf{c})}$ & $\mathrm{Et}_{2} \mathrm{Zn}$ & $c$-Hexyl & $\mathbf{4 0 c}$ & 41 & $90 \% \mathrm{de}$ \\
\hline
\end{tabular}

a) Isolated yields of major diastereomer 40a-c. $b$ ) Reactions were carried out with $\mathrm{Et}_{3} \mathrm{~B}$ or $\mathrm{Et}_{2} \mathrm{Zn}$ (5.0 equiv) in $\mathrm{CH}_{2} \mathrm{Cl}_{2}$ at $-78^{\circ} \mathrm{C} . c$ ) Reactions were carried out with $\mathrm{Et}_{3} \mathrm{~B}$ or $\mathrm{Et}_{2} \mathrm{Zn}$ (10 equiv) in RI/ toluene $(4: 1, \mathrm{v} / \mathrm{v})$ at $0^{\circ} \mathrm{C}$.

となるスズ化合物の除去が, レジンを溶媒で洗浄す るだけ達成できる利点がある.

次に, 液相反応で用いたアミノ酸の不斉合成反応 をモデル反応として, 固相ラジカル反応の立体制御 の可能性を検索した. ${ }^{54)} \mathrm{Et}_{3} \mathrm{~B}$ を用いてオキシムエー テル 39 へのエチルラジカル付加反応を低温で検討 した (Table 2, entry 1)。 その結果, 固相ラジカル 反応は期待通り高立体選択的に進行し，TFAによ るレジンからの切り離しを経て, アミノ酸誘導体 40a が 74\%の収率で得られた。同様に, $\mathrm{Et}_{2} \mathrm{Zn}$ を 用いた場合にも高ジアステレオ選択的に反応が進行 した (entry 2)。さらに, 反応条件として， $\mathrm{Bu}_{3}$ $\mathrm{SnH}$ を用いない環境にやさしいヨウ素原子移動反 応を適用し, 他のアルキルラジカルとの反応を検討 した. しかし, 固相反応においては, ルイス酸性を 有する $\mathrm{Et}_{3} \mathrm{~B} や \mathrm{Et}_{2} \mathrm{Zn}$ が固相上のオキシムエーテル 基に配位して, レジン表面に集積したために, 顕著 なエチルラジカル付加反応が観測された。 そこで, 過剩の試薬を容易に除去できる固相反応の利点を考 慮して, RI : toluene $(4: 1)$ 懸濁溶液中で反応を
行ったところ, 目的の付加体が選択的に得られた (entries 3-6)。このように, $\mathrm{Et}_{3} \mathrm{~B}$ や $\mathrm{Et}_{2} \mathrm{Zn}$ はレジン のポリスチレン部に邪魔されることなく, 固相反応 においても有効なラジカル開始剤として働くことが 判明した。 本固相反応は, 溶媒や試薬の特別な精製 を必要とせず，市販品をそのまま用いることができ ることから，コンビナトリアル合成法に適応しやす い反応と言える. また, 本反応のように, ラジカル 反応を用いれば厳密な無水条件や脱酸素条件を必要 とせず，固相上で容易に炭素一炭素結合を形成する ことができる.

次に, 分子内で炭素一炭素結合を形成することを 目的として, オキシムエーテル類 $\mathbf{4 1}$ の固相ラジカ ル閉環反応を検討した (Scheme 14). ${ }^{55)}$ 加熱条件下, $\mathrm{Bu}_{3} \mathrm{SnH}$ と $\mathrm{Et}_{3} \mathrm{~B}$ を用いてオキシムエーテル $41 \mathrm{~A} の$ 反応を行つたところ, 目的の閉環体 $42 \mathrm{Aa}$ が得られ た. スタニルラジカル付加一閉環反応の推定反応経 路を示した (Scheme 15)。本反応は, $\mathrm{Et}_{3} \mathrm{~B}$ からの エチルラジカルの発生により始まり, 続いてスタニ ルラジカルが生成する. スタニルラジカルがトリエ 


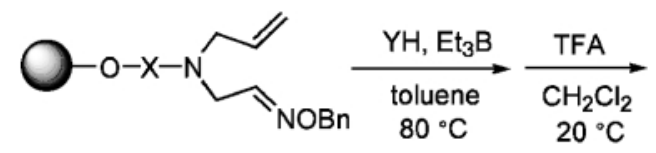

$41 \mathrm{~A}$

a $: Y=\mathrm{SnBu}_{3}$

b $: Y=S i(T M S)_{3}$<smiles>[Y]CC1CN([X])CC1NOCc1ccccc1</smiles>

42Aa $(64 \%)$

42Ab $(50 \%)$

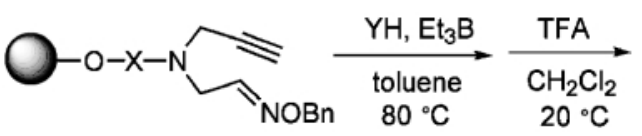

41B

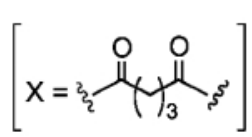<smiles>[R]C=C1CN([X]O)CC1NOC(C)(C)C</smiles>

Scheme 14. Solid-Phase Radical Cyclization

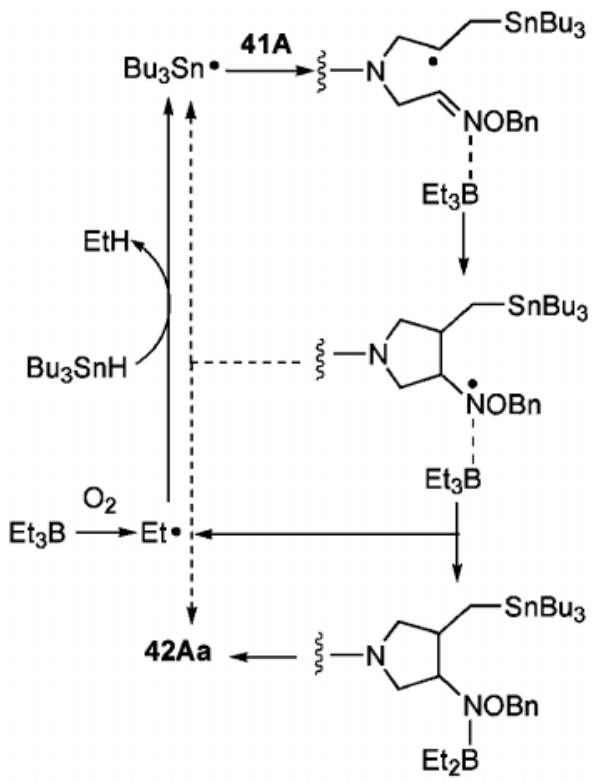

Scheme 15. Possible Reaction Pathway

チルボランにより活性化されたオキシムエーテル 41A に付加一閉環することにより，中間体アミニ ルラジカルが生成する，その後，2つの経路が考え られるが, 最近の著者らの研究から, ${ }^{20,21)} \mathrm{Bu}_{3} \mathrm{SnH}$ ではなく $\mathrm{Et}_{3} \mathrm{~B}$ がラジカル停止剤として働き, エチ ルラジカルの再生を伴い反応が進行する経路が主経 路であると考えている。 また，トリストリメチルシ リルシランを用いた場合にも目的の反応が進行し, 50\% の収率で閉環体 $\mathbf{4 2 A b}$ が得られた。さらに，
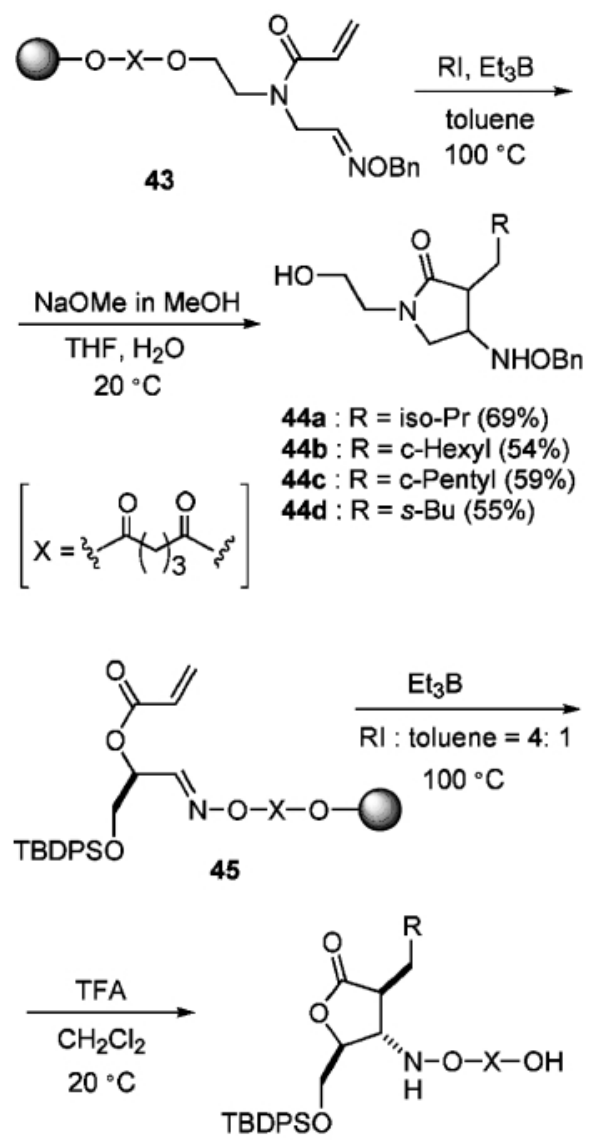

46a $: R=$ iso- $\operatorname{Pr}(57 \%, 8: 1 \mathrm{ds})$

46b : R = c-Hexyl $(50 \%, 8: 1 \mathrm{ds})$

$46 c: R=$ Ethyl $(92 \%, 8: 1 d s)$

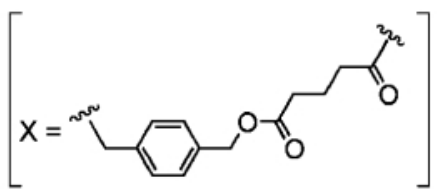

Scheme 16. Solid-Phase Tandem Radical Reaction

末端に 3 重結合を有するオキシムエーテル 41B の 付加一閉環反応を検討した。 $\mathrm{Et}_{3} \mathrm{~B}$ と $\mathrm{Bu}_{3} \mathrm{SnH}$ を用 いて，トルエン中で加温したところ反応は速やかに 進行し，77\% の収率で閉環体 42Ba が得られた。以 上のように, 固相反応において, トリエチルボラン は加熱条件下でも効果的に㗢くことが判明した.

次に, 固相上で 2 つ炭素一炭素結合を一段階で 形成するタンデム型炭素ラジカル付加一閉環反応の 開発に着手した（Scheme 16）. ${ }^{56)}$ 基質としては, 電 子的性質が異なる 2 つラジカル受容体 $\alpha, \beta$-不飽 和カルボニル基とオキシムエーテル基を有する基質 43 と 45 を選び, 固相タンデム反応を検討した。は じめに，アキラルな基質 $\mathbf{4 3}$ のラジカル付加一閉環 反応を加熱条件下で検討したところ, 目的のタンデ 


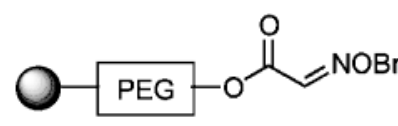

TentaGel $\mathrm{OH}$ resin

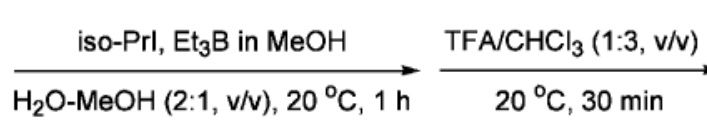

Scheme 17. Solid-Phase Radical Reaction in Water

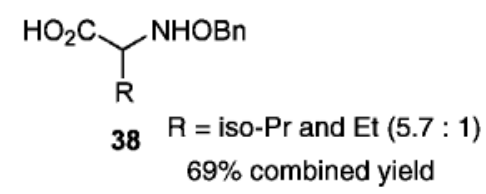

ム型反応が進行し，2つの炭素一炭素結合が形成さ れた閉環体 44a-d が得られた．次に，キラルなオキ シムエーテル 45 のタンデム型ラジカル付加一閉環 反応を検討した結果, 目的のアルキル体を得るため には RI : toluene $(4: 1)$ 懸濁溶液中で反応を行う 必要があったが, 反応はジアステレオ選択的に進行 した。

最後に，ラジカル開始剤として $\mathrm{Et}_{3} \mathrm{~B}$ を用いて, ポリエーテルリンカー部を有する TentaGel OH re$\sin$ に担持したオキシムエーテル 47 の水溶媒中固相 ラジカル反応を検討した（Scheme 17）。 ${ }^{57)}$ オキシム エーテル 47 の反応を水一メタノール混合溶媒中で 検討した結果, トリエチルボランのメタノール溶液 をラジカル開始剤として用いた場合に, 目的の固相 反応が速やかに進行することが分かった。現段階 で, 目的のイソプロピル体とエチル体の選択性は低 いものの, 親水性を有する TentaGel $\mathrm{OH}$ resin を用 いることにより, 水溶媒系においても固相ラジカル 反応が行えることが判明した。

\section{6. おわりに}

ラジカル反応の有機合成への利用は，イオン反 応, 協奏反応, 有機金属反応に並び, 興味ある分野 である. 特に, 水中でも利用可能な中性ラジカルの 反応は厳密な無水条件を必要とせず, 様々な反応系 に展開できることから今後の発展が期待できる.

\section{謝辞本研究を行うにあたり, 御指導と御支援} を賜わりました内藤猛章神戸薬科大学教授に厚くお 礼申し上げます。また, 本研究は, 今西武大阪大 学大学院薬学研究科教授, 竹本佳司京都大学大学院 薬学研究科教授の御支援と共同研究者の御協力のも と行われた研究であり, 深く感謝いたします。な お, 本研究は, 神戸薬科大学, 日本学術振興会奨励 研究 A, 第 11 回有機合成化学協会「研究企画賞」 (日産化学工業), 武田科学振興財団薬学系研究奨励 助成並びに医薬資源研究振興会研究奨励助成の御支
援によって行われたものであり，併せて感謝いたし ます。

\section{REFERENCES}

1) Bloch R., Chem. Rev., 98, 1407-1438 (1998).

2) Enders D., Reinhold U., Tetrahedron Asymmetry, 8, 1895-1946 (1998).

3) Denmark S. E., Nicaise O. J.-C., Chem. Commun., 999-1004 (1997).

4) Naito T., Heterocycles, 50, 505-541 (1999).

5) Fallis A. G., Brinza I. M., Tetrahedron, 53, 17543-17594 (1997).

6) Iserloh U., Curran D. P., J. Org. Chem., 63, 4711-4710 (1998).

7) Boiron A., Zillig P., Faber D., Giese, B., J. Org. Chem., 63, 5877-5882 (1998).

8) Marco-Contelles J., Gallego P., RodríguezFernández M., Khiar N., Destabel C., Bernabé M., Martínez-Grau A., Chiara J. L., J. Org. Chem., 62, 7397-7412 (1997).

9) Clive D. L. J., Zhang J., Chem. Commun., 549-550 (1997).

10) Keck G. E., Wager T. T., J. Org. Chem., 61, 8366-8367 (1996).

11) Hollingworth G. J., Pattenden G., Schulz D. J., Aust. J. Chem., 48, 381-399 (1995).

12) Parker K. A., Fokas D., J. Org. Chem., 59, 3927-3932 (1994).

13) Miyabe H., Naito T., J. Synth Org. Chem., Jpn. 59, 33-39 (2001).

14) Hart D. J., Seely F. L., J. Am. Chem. Soc., 110, 1631-1633 (1988).

15) Hanamoto T., Inanaga J., Tetrahedron Lett., 32, 3555-3556 (1991).

16) Bhat B., Swayze E. E., Wheeler P., Dimock S., Perbost M., Sanghvi Y. S., J. Org. Chem., 61, 8186-8199 (1996).

17) Kim S., Lee I. Y., Yoon J.-Y., Oh D. H., $J$. Am. Chem. Soc., 118, 5138-5139 (1998).

18) Miyabe H., Shibata R., Ushiro C., Naito T., 
Tetrahedron Lett., 39, 631-634 (1998).

19) Miyabe H., Shibata R., Sangawa M., Ushiro C., Naito T., Tetrahedron, 54, 11431-11444 (1998) .

20) Miyabe H., Yamakawa K., Yoshioka N., Naito T., Tetrahedron, 55, 11209-11218 (1999).

21) Miyabe H., Ueda M., Yoshioka N., Naito T., Synlett, 465-467 (1999).

22) “Radicals in Organic Synthesis,"' eds. by Sibi M. P., Renaud P., Wiley-VCH, New York, 2001.

23) Miyabe H., Ushiro C., Naito T., Chem. Commun., 1789-1790 (1997).

24) Miyabe H., Ushiro C., Ueda M., Yamakawa K., Naito T., J. Org. Chem., 65, 176-185 (2000).

25) Ryu I., Araki F., Minakata S., Komatsu M., Tetrahedron Lett., 39, 6335-6336 (1998).

26) Miyabe H., Fujii K., Naito T., Org. Lett., 1, 569-572 (1999).

27) Miyabe H., Fujii K., Naito T., Org. Biomol. Chem., 1, 381-390 (2003).

28) Ueda M., Miyabe H., Teramachi M., Miyata O., Naito T., Chem. Commun., 426-427 (2003).

29) Miyabe H., Yoshioka N., Ueda M., Naito T., J. Chem. Soc., Perkin Trans. 1, 3659-3660 (1998).

30) Miyabe H., Ueda M., Yoshioka N., Yamakawa K., Naito T., Tetrahedron, 56, 2413-2420 (2000) .

31) Yorimitsu H., Nakamura T., Shinokubo H., Oshima K., J. Org. Chem., 63, 8604-8605 (1998) .

32) Miyabe H., Ueda M., Naito T., J. Org. Chem., 65, 5043-5047 (2000).

33) Miyabe H., Ueda M., Naito T., Chem. Commun., 2059-2060 (2000).

34) Miyabe H., Ueda M., Nishimura A., Naito T., Org. Lett., 4, 131-134 (2002).

35) Miyabe H., Nishimura A., Ueda M., Naito T., Chem. Commun., 1454-1455 (2002).

36) Miyabe H., Miyata K., Naito T., J. Synth. Org. Chem., Jpn. 60, 1087-1094 (2002) .
37) Miyabe H., Torieda M., Inoue K., Tajiri K., Kiguchi T., Naito, T., J. Org. Chem., 63, 4397 -4407 (1998).

38) Miyabe H., Kanehira S., Kume K., Kandori H., Naito T., Tetrahedron, 54, 5883-5892 (1998)

39) Miyabe H., Torieda M., Kiguchi T., Naito T., Synlett, 580-582 (1997).

40) Miyabe H., Nishiki A., Naito T., Chem. Pharm. Bull., 51, 100-103 (2003).

41) Miyabe H., Fujii K., Goto T., Naito T., Org. Lett., 2, 4071-4074 (2000).

42) Brown R. C. D., J. Chem. Soc., Perkin Trans. 1, 3293-3320 (1998).

43) Brown R. C. D., Chem. Rev., 97, whole issue of No. 2, pp 347-510 (1997).

44) Hermkens P. H. H., Ottenheijm H. C. J., Rees D. C., Tetrahedron, 53, 5643-5678 (1997).

45) Miyabe H., Yakugaku Zasshi, 120, 667-676 (2000).

46) Naito T., Miyabe H., J. Synth. Org. Chem., Jpn. 60, 484-485 (2002) .

47) Sibi M. P., Chandramouli S. V., Tetrahedron Lett., 38, 8929-8932 (1997).

48) Routledge A., Abell C., Balasubramanian S., Synlett, 61-62 (1997).

49) Du X., Armstrong R. W., J. Org. Chem., 62, 5678-5679 (1997).

50) Du X., Armstrong R. W., Tetrahedron Lett., 39, 2281-2284 (1998).

51) Berteina S., De Mesmaeker A., Tetrahedron Lett., 39, 5759-5762 (1998).

52) Berteina S., Wendeborn S., De Mesmaeker A., Synlett, 1231-1233 (1998) .

53) Miyabe H., Fujishima Y., Naito T., J. Org. Chem., 64, 2174-2175 (1999).

54) Miyabe H., Konishi C., Naito T., Org. Lett., 2, 1443-1445 (2000).

55) Miyabe H., Tanaka H., Naito T., Tetrahedron Lett., 40, 8387-8390 (1999).

56) Miyabe H., Fujii K., Tanaka H., Naito T., Chem. Commun., 831-832 (2001).

57) Miyabe H., Nishimura A., Fujishima Y., Naito T., Tetrahedron, 59, 1901-1907 (2003). 